\title{
Trend in Area, Production and Productivity of all Rice and boro Rice in Bihar State
}

\author{
Deepak Kumar Skand ${ }^{1 *}$, Mukesh Kumar Wadhwani ${ }^{2}$ and M. Rahaman ${ }^{3}$ \\ Department of Agricultural Economics, Bihar Agricultural University, \\ Sabour, Bhagalpur- 813210 \\ *Corresponding author
}

\section{Keywords \\ Trend, CAGR, Garrett Score, boro rice, Zone II Bihar \\ Article Info \\ Accepted: \\ 15 August 2020 \\ Available Online: \\ 10 September 2020}

\section{A B S T R A C T}

Rice occupies a pivotal place in Indian agriculture and provides $43 \%$ calorie requirement for more than $70 \%$ of its people. It accounts for about $42 \%$ of total food grain production and 55\% of cereal production in the country. The CGAR (from 1997-98 to 2017-18) of area, production and productivity under all rice was found as 1.09 per cent, 0.68 per cent and 0.62 per cent, respectively, while that of boro rice it was found as 1.73 per cent, 1.58 per cent and 0.91 per cent, respectively. The annual growth rate for the same period of all rice in zone II of Bihar was 1.18 percent for area, 0.84 per cent for production and 0.72 per cent for productivity while that of boro rice of was 1.60 for area, 1.44 per cent for production and 0.90 per cent for productivity. Thereby showing that area, production and productivity of all rice and boro rice has increased from 1997-98 to 2017-18 in the state. In Bihar state rice is grown in 3.30 million hectares, covering 60 percent of Net Cropped Area, producing8.09 million tonnes with the productivity of $2447 \mathrm{~kg} / \mathrm{ha}$ (DES, 2017-18). The productivity of the crop in the state is far below the national average $(2578 \mathrm{Kg} / \mathrm{ha})$. In the state, rice is grown in versatile adaptation from precarious moisture as rainfed upland to deep water area having 3-4 meter water as deep water crop with many intermediate situations in between. The diverse ecological situation, varying climate and pedagogical conditions along with socio-economic diversities make rice cultivation a highly risky venture, resulting in overall poor productivity of the crop in the state. In Bihar around 33 percent of the total rice area in the state is under assured irrigation while remaining 67 percent is under rainfed situation. A large tract of land of Bihar state becomes unsuitable for traditional kharif crops due to flood and water logging from rivers and its tributaries from July to October months. The cultivation of rice during rabi crop season (November to May) was unknown probably till the new rice cultivars were introduced in eastern part of India through Bangladesh refugees. The cultivation of rice during winter months is termed as 


\section{Introduction}

India is the second largest producer, consumer and exporter of rice after China. Rice is the most dominant cereal crop accounting 45 per cent of the total food grain production of the country. India produced 112.91 million tonnes of rice from an area of 43.79 million ha during 2017-18. However, the country ranked $9^{\text {th }}$ in terms of productivity $\left(2578 \mathrm{~kg} \mathrm{ha}^{-1}\right)$ in the world which is far below the world average of $3173 \mathrm{~kg} / \mathrm{ha}$ (DES,2017-18). It occupies a pivotal place in Indian agriculture and provides $43 \%$ calorie requirement for more than $70 \%$ of its people. It accounts for about $42 \%$ of total food grain production and $55 \%$ of cereal production in the country. It is cultivated in three seasons i.e. Aus (April to June), Aman (June to November) and Boro (November to April) rice in India.

In Bihar staterice is grown in 3.30 million hectares, covering 60 percent of Net Cropped Area, producing8.09 million tonnes with the productivity of $2447 \mathrm{~kg} / \mathrm{ha}$ (DES, 2017-18). The productivity of the crop in the state is far below the national average $(2578 \mathrm{Kg} / \mathrm{ha})$. In the state, rice is grown in versatile adaptation from precarious moisture as rainfed upland to deep water area having 3-4 meter water as deep water crop with many intermediate situations in between. The diverse ecological situation, varying climate and pedagogical conditions along with socio-economic diversities make rice cultivation a highly risky venture, resulting in overall poor productivity of the crop in the state. In Bihar around 33 percent of the total rice area in the state is under assured irrigation while remaining 67 percent is under rainfed situation.

A large tract of land of Bihar state becomes unsuitable for traditional kharif crops due to flood and water logging from rivers and its tributaries from July to October months. The cultivation of rice during rabi crop season
(November to May) was unknown probably till the new rice cultivars were introduced in eastern part of India through Bangladesh refugees. The cultivation of rice during winter months is termed as boro rice. Boro is a Bengali word derived from Sanskrit word 'Borob' that refers to special rice cultivation in low land pockets during November to May months. The farmers innovated this rice cultivation with short duration photoperiod insensitive varieties to supplement poor kharif harvest. The boro rice area in eastern states of Assam, Odisha and West Bengal are mainly distributed in swampy low lands. In Bihar, it is spread in low lying belts of North-Eastern districts namely Purnea, Saharsa, Madhepura, Kisanganj, Supaul, Darbhanga, Katiharand North -Western districts viz. East Champaran and West Champaran, where rain water is accumulated and remains stagnated beyond October month. Recently with the introduction of cold tolerant rice varieties boro rice has become boon to the farmers of this region.

\section{Materials and Methods}

The study was based the time-series data on area, production and productivity of all rice as well as of boro rice in Bihar state and its zone II (from 1997-98 to 2017-18) were collected from various published sources. The data were summarized, tabulated and analyzed using statistical measures like trend analysis.

\section{Trend analysis}

The trend in area, production and productivity were analyzed on the basis of Compound Annual Growth Rate (CAGR). The formula used for estimation of CAGR was as;

$C A G R=\left\{(y n / y 1)^{\wedge} 1 / n\right\}-1$

Where, $\mathrm{y}_{1}=$ Data $\left(\mathrm{I}^{\mathrm{st}}\right.$ year $)$; 
$\mathrm{y}_{\mathrm{n}}=$ Data $\left(\mathrm{n}^{\text {th }}\right.$ year $)$ and

$\mathrm{n}=$ No. of years.

\section{Results and Discussion}

Trend in area, production and productivity of total rice and boro rice in Bihar \& Zone II from 1997-98 to 2017-18

The Compound Annual Growth Rate (CAGR) of total rice in Bihar is presented table 1, which reveals that CAGR for area, production and productivity $1.09,0.68$ per cent and 0.62 per cent, respectively and of boro rice in the state was estimated as $1.73,1.58$ and 0.91 per cent, respectively. It shows that area, production and productivity of total rice as well as of boro rice has increased in Bihar. It is also indicated from the table that area, production and productivity under boro rice increased more as compared to all rice in the state during the period from 199798 to $2017-18$.

The Compound Annual Growth Rate of total rice in zone II (Bihar) from 1997-98 to 201718 was found to be 1.18 per cent for area, 0.84 per cent for production and 0.72 per cent for productivity. The CAGR of boro rice in zone II of the state was $1.60,1.44$ and 0.90 per cent for area, production and productivity, respectively. It shows the area, production and productivity of boro rice increased more as compared to total rice in zone II also. The area, production and productivity of boro rice in state increased more as compared to zone II (Fig. 2 and 4).
Trend in area, production \& productivity of total rice cultivation (District-wise) in Zone II

The trend in area, production \& productivity of total rice in Zone II (District-wise)of Biharis presented in table 2. The table reveals that CAGR of area oftotal rice for the districts of Araria, Katihar, Khagaria, Kisanganj, Madhepura, Purnea, Saharsa and Supaul of zone II was estimated as 0.77, 2.30, 1.23, $1.23,1.16,1.16,1.32$ and 1.10 per cent, respectively. The CAGR for production was found to be $0.58,1.56,0.58,0.84,1.06,0.76$, 0.79 and 0.81 per cent, respectively for the above districts. It is revealed that highest increase in area $(2.30$ per cent $)$ and production (1.56) was recorded in Katihar district, while highest increase in productivity was (0.92) in Madhepura district.

The trend in area, production and productivity of bororice in Zone II (district-wise) is also presented in table 2 . It is revealed from the table that highest CAGR of area (6.61 per cent) and production (5.18 per cent) of boro rice was found in Saharsa district while that of highest productivity (1.03 per cent) was estimated for Kishanganj district of zone II. The CGAR of area, production and productivity in all districts of zone II was positive thereby indicated increase of these in all districts during the reference period (199798 to 2017-18) (Fig. 1 and 3; Table 3).

Table.1 Trend in area, production and productivity of total rice and boro rice in Bihar \&Zone II (per cent) from 1997-98 to 2017-18

\begin{tabular}{|l|c|c|c|}
\hline \multicolumn{1}{|c|}{ Particulars } & Area & Production & Productivity \\
\hline Total Rice (Bihar) & 1.09 & 0.68 & 0.62 \\
\hline Total Rice (Zone II) & 1.18 & 0.84 & 0.72 \\
\hline Total boro rice (Bihar) & 1.73 & 1.58 & 0.91 \\
\hline Total boro rice (Zone II) & 1.60 & 1.44 & 0.90 \\
\hline
\end{tabular}

The data for study period is appended in Appendix and presented graphically. 
Table.2 Trend in area, production and productivity of total rice and boro rice in Zone II of Bihar (Per cent)

\begin{tabular}{|l|c|c|c|c|c|c|}
\hline \multirow{2}{*}{ District } & \multicolumn{3}{|c|}{ Total rice (Zone II) } & \multicolumn{3}{c|}{ Total boro rice (Zone II) } \\
\cline { 2 - 7 } & Area & Production & Productivity & Area & Production & Productivity \\
\hline Araria & 0.77 & 0.58 & 0.75 & 1.02 & 1.03 & 1.01 \\
\hline Katihar & $\mathbf{2 . 3 0}$ & $\mathbf{1 . 5 6}$ & 0.68 & 1.42 & 1.17 & 0.82 \\
\hline Khagaria & 1.23 & 0.58 & 0.47 & 0.85 & 0.66 & 0.78 \\
\hline Kisanganj & 1.23 & 0.84 & 0.69 & 0.70 & 0.72 & $\mathbf{1 . 0 3}$ \\
\hline Madhepura & 1.16 & 1.06 & $\mathbf{0 . 9 2}$ & 4.46 & 4.57 & 1.02 \\
\hline Purnea & 1.16 & 0.76 & 0.66 & 3.18 & 3.08 & 0.97 \\
\hline Saharsa & 1.32 & 0.79 & 0.60 & $\mathbf{6 . 6 1}$ & $\mathbf{5 . 1 8}$ & 0.78 \\
\hline Supaul & 1.10 & 0.81 & 0.74 & 3.00 & 2.50 & 0.83 \\
\hline
\end{tabular}

Table.3 Area, production and productivity of rice in Bihar

\begin{tabular}{|c|c|c|c|}
\hline Year & $\begin{array}{c}\text { Area } \\
\left({ }^{\circ} 000 \text { ha }\right)\end{array}$ & $\begin{array}{l}\text { Production } \\
\text { ('000 tonnes) }\end{array}$ & $\begin{array}{l}\text { Productivity } \\
\text { (Kg/ha) }\end{array}$ \\
\hline $1997-98$ & 3621.33 & 5395.08 & 1489.81 \\
\hline 1998-99 & 3110.89 & 4670.65 & 1501.39 \\
\hline 1999-00 & 665.47 & 945.25 & 1420.44 \\
\hline 2000-01 & 3656.84 & 5444.37 & 1488.82 \\
\hline 2001-02 & 3564.54 & 5301.22 & 1487.21 \\
\hline $2002-03$ & 3584.70 & 5085.57 & 1418.69 \\
\hline 2003-04 & 3667.66 & 5568.09 & 1518.16 \\
\hline 2004-05 & 3140.12 & 2472.16 & 787.28 \\
\hline 2005-06 & 3251.24 & 3709.29 & 1140.88 \\
\hline 2006-07 & 3364.01 & 5027.95 & 1494.63 \\
\hline 2007-08 & 3477.37 & 4458.98 & 1599.30 \\
\hline 2008-09 & 3495.27 & 5589.98 & 1599.30 \\
\hline 2009-10 & 3124.03 & 3640.21 & 1165.23 \\
\hline 2010-11 & 2845.37 & 3112.62 & 1093.92 \\
\hline 2011-12 & 3350.94 & 8237.97 & 2458.41 \\
\hline 2012-13 & 3298.89 & 8322.01 & 2522.67 \\
\hline 2013-14 & 3150.81 & 6649.59 & 2110.44 \\
\hline 2014-15 & 3263.37 & 8241.62 & 2525.49 \\
\hline 2015-16 & 3232.31 & 6802.22 & 2104.44 \\
\hline 2016-17 & 3339.78 & 8238.77 & 2466.86 \\
\hline 2017-18 & 3306.98 & 8093.16 & 2447.29 \\
\hline CAGR (\%) & 1.09 & 0.68 & 0.62 \\
\hline
\end{tabular}

Source: https://aps.dac.gov.in/ 
Table.2 Area, production and productivity of boro rice in Bihar

\begin{tabular}{|c|c|c|c|}
\hline Year & $\begin{array}{c}\text { Area } \\
\text { ('000 ha) }\end{array}$ & $\begin{array}{l}\text { Production } \\
\text { ('000 tonnes) }\end{array}$ & $\begin{array}{c}\text { Productivity } \\
\text { (Kg/ha) }\end{array}$ \\
\hline 1997-98 & 120.94 & 231.89 & 1917.40 \\
\hline 1998-99 & 128.80 & 264.46 & 2053.30 \\
\hline 1999-00 & 124.87 & 246.81 & 1976.45 \\
\hline 2000-01 & 126.13 & 214.18 & 1698.12 \\
\hline 2001-02 & 182.25 & 195.59 & 1073.21 \\
\hline 2002-03 & 120.32 & 197.56 & 1073.21 \\
\hline 2003-04 & 116.89 & 169.90 & 1450.58 \\
\hline 2004-05 & 116.22 & 166.20 & 1430.03 \\
\hline 2005-06 & 113.25 & 182.83 & 1614.35 \\
\hline 2006-07 & 109.44 & 163.99 & 1498.49 \\
\hline 2007-08 & 110.44 & 172.29 & 1560.04 \\
\hline 2008-09 & 105.53 & 178.24 & 1689.06 \\
\hline 2009-10 & 95.67 & 176.64 & 1846.42 \\
\hline 2010-11 & 84.46 & 163.01 & 1930.08 \\
\hline 2011-12 & 96.16 & 182.65 & 1899.39 \\
\hline 2012-13 & 105.10 & 285.79 & 2719.23 \\
\hline 2013-14 & 92.21 & 215.95 & 2342.03 \\
\hline 2014-15 & 82.27 & 181.56 & 2206.95 \\
\hline 2015-16 & 81.07 & 200.42 & 2472.29 \\
\hline 2016-17 & 84.32 & 224.33 & 2660.35 \\
\hline 2017-18 & 67.87 & 143.83 & 2119.38 \\
\hline CAGR (\%) & 1.73 & 1.58 & 0.91 \\
\hline
\end{tabular}

Source: https://aps.dac.gov.in/ 
Table.3 Area, production and productivity of rice in Zone II of Bihar

\begin{tabular}{|c|c|c|c|}
\hline Year & $\begin{array}{c}\text { Area } \\
\text { ('000 ha) }\end{array}$ & $\begin{array}{l}\text { Production } \\
\text { ('000 tonnes) }\end{array}$ & $\begin{array}{c}\text { Productivity } \\
\text { (Kg/ha) }\end{array}$ \\
\hline 1997-98 & 784.817 & 1006.271 & 1282.17 \\
\hline 1998-99 & 657.846 & 753.811 & 1145.88 \\
\hline 1999-00 & 232.370 & 335.949 & 1445.75 \\
\hline 2000-01 & 816.142 & 1016.100 & 1245.00 \\
\hline 2001-02 & 786.944 & 885.950 & 1125.81 \\
\hline 2002-03 & 791.625 & 903.155 & 1140.89 \\
\hline 2003-04 & 877.709 & 1190.465 & 1356.33 \\
\hline 2004-05 & 741.595 & 623.144 & 840.28 \\
\hline 2005-06 & 751.058 & 810.448 & 1079.08 \\
\hline 2006-07 & 742.048 & 791.260 & 1066.32 \\
\hline 2007-08 & 732.334 & 676.272 & 923.45 \\
\hline 2008-09 & 684.893 & 766.827 & 1119.63 \\
\hline 2009-10 & 722.054 & 870.152 & 1205.11 \\
\hline 2010-11 & 680.157 & 785.162 & 1154.38 \\
\hline 2011-12 & 707.524 & 1306.333 & 1846.34 \\
\hline 2012-13 & 705.698 & 1517.307 & 2150.76 \\
\hline 2013-14 & 706.496 & 1476.594 & 2090.02 \\
\hline 2014-15 & 687.362 & 1557.307 & 2265.63 \\
\hline 2015-16 & 669.644 & 1322.969 & 1975.63 \\
\hline 2016-17 & 714.761 & 1513.372 & 2117.31 \\
\hline 2017-18 & 660.056 & 1202.453 & 1821.75 \\
\hline CAGR (\%) & 1.18 & 0.84 & 0.72 \\
\hline
\end{tabular}

Source: https://aps.dac.gov.in/ 
Table.4 Area, Production and Productivity of boro rice in zone II of Bihar

\begin{tabular}{|c|c|c|c|}
\hline Year & $\begin{array}{c}\text { Area } \\
\left({ }^{(} 000 \text { ha }\right)\end{array}$ & $\begin{array}{l}\text { Production } \\
\text { ('000 tonnes) }\end{array}$ & $\begin{array}{c}\text { Productivity } \\
\text { (Kg/ha) }\end{array}$ \\
\hline 1997-98 & 95.23 & 188.729 & 1981.82 \\
\hline 1998-99 & 102.608 & 230.31 & 2244.56 \\
\hline 1999-00 & 101.71 & 214.124 & 2105.24 \\
\hline 2000-01 & 103.654 & 176.325 & 1701.09 \\
\hline 2001-02 & 138.931 & 138.629 & 997.83 \\
\hline 2002-03 & 98.571 & 158.559 & 1608.58 \\
\hline 2003-04 & 96.209 & 144.268 & 1499.53 \\
\hline 2004-05 & 95.037 & 135.59 & 1426.71 \\
\hline 2005-06 & 93.872 & 163.815 & 1745.09 \\
\hline 2006-07 & 90.691 & 136.16 & 1501.36 \\
\hline 2007-08 & 90.791 & 141.833 & 1562.19 \\
\hline 2008-09 & 88.713 & 150.172 & 1692.78 \\
\hline 2009-10 & 83.294 & 160.256 & 1923.98 \\
\hline 2010-11 & 74.264 & 145.704 & 1961.97 \\
\hline 2011-12 & 90.353 & 172.561 & 1909.85 \\
\hline 2012-13 & 91.791 & 256.453 & 2793.88 \\
\hline 2013-14 & 75.904 & 181.939 & 2396.96 \\
\hline 2014-15 & 68.119 & 156.834 & 2302.35 \\
\hline 2015-16 & 68.513 & 170.119 & 2483.02 \\
\hline 2016-17 & 73.08 & 200.879 & 2748.75 \\
\hline 2017-18 & 58.19 & 129.046 & 2217.67 \\
\hline CAGR (\%) & 1.60 & 1.44 & 0.90 \\
\hline
\end{tabular}

Source: https://aps.dac.gov.in/ 
Figure.1 Area, production and productivity of rice in Bihar

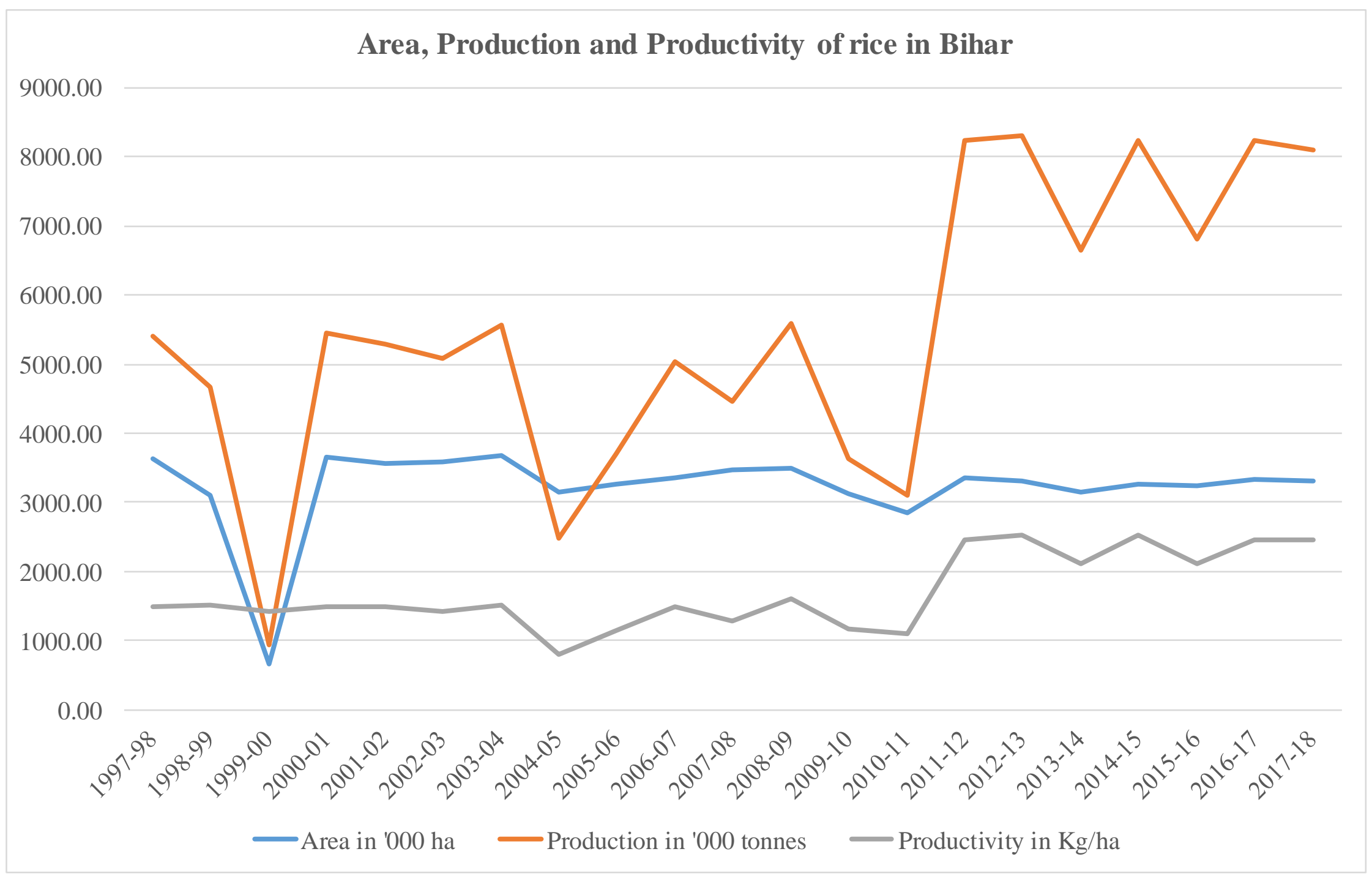


Figure.2 Area, production and productivity of boro rice in Bihar

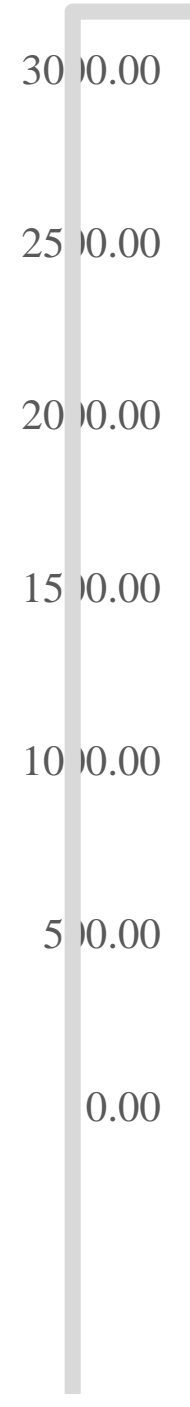


Figure.3 Area, production and productivity of rice in Zone II of Bihar

A rea Production and Productivity of rice in zone II of Rihar

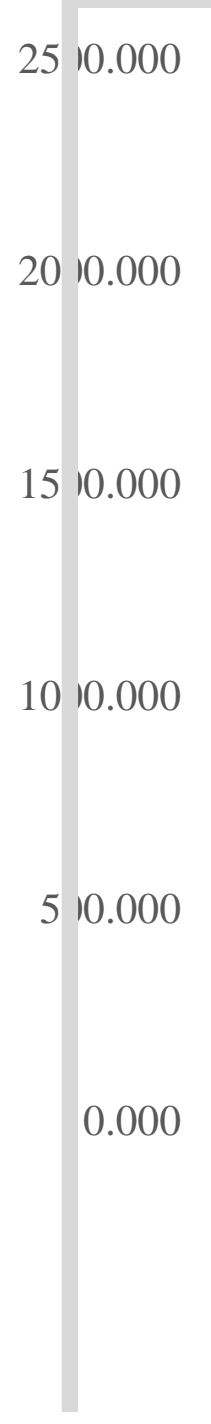


Figure.4 Area, production and productivity of boro rice in zone II of Bihar

A rea. Production and Productivity of horo rice in zone II of Rihar

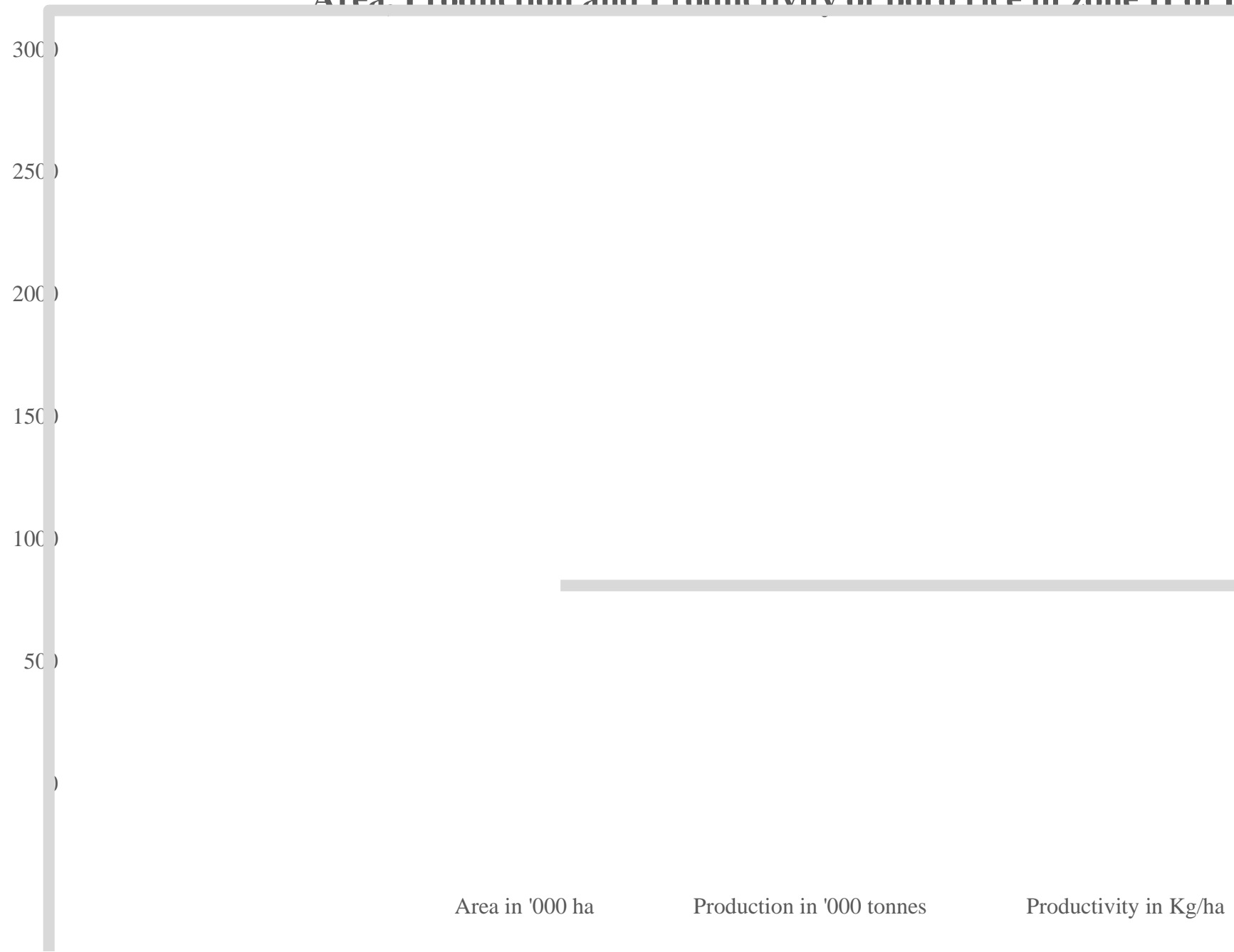


It may be concluded from the study that area, production and productivity of boro rice has increase more as compared to total rice in Bihar. The probable reason for this may be because of that boro rice system takes advantage of residual moisture after the harvest of kharifrice. Such area with high moisture retention capacity are lowlying ditches where water is stored or gets accumulated, areas adjoining canals and roads, Chaur-lands/Tal lands, etc are suitable for boro rice cultivation. Boro rice is a winter season, photo insensitive, transplanted rice cultivated with supplemental irrigation. It gives the farmers a chance to grow a rabiseason crop, which normally they could not grow.

In the state boro rice is normally grown under irrigated condition. The average rainfall in in Bihar as well as in zone II is high but it does not distribute uniformly, so at the time of rice cultivation, it cannot meet the actual water requirement of the crop in respect to time and space. Therefore, a long area of cultivable land remains fallow during winter season due to insufficient soil moisture. With the increase in irrigation facilities, boro rice crop is now being taken in areas outside its traditional boundaries and a new cropping system is emerging (Singh, 2003).Irrigation can therefore bring more areas under boro rice cultivation. Another factor that affects the boro rice cultivation is fall of water table below ground surface. Lack of appropriate variety and water management practice is a limiting factor for successful boro rice cultivation under shrinking water condition. Therefore, appropriate agronomic management is a prerequisite to exploit full potential of the available resources. To realize the maximum possible benefits from boro rice, it is essential to develop appropriate package of practices for successful cultivation and yield maximization. Among the various cultural practices appropriate varieties and water management practice may play important for yield maximization.

\section{Acknowledgement}

The paper is based on M.Sc. (Ag) in Agricultural Economics thesis research of the first author done under the supervision of second author, Bihar Agricultural University, Sabour. The assistance provided by all is duly acknowledged.

\section{References}

Akhter S, Sarker JR, Das KR (2016) Growth and trend in area, production and yield of major crops of Bangladesh International Journal of Economics, Finance and Management Sciences 2016; 4(1): 20-25, January 27, 2016 ISSN: $2326-9553$.

Kannan E, Sundaram S (2011) Analysis of trends in India's agricultural growth, The Institute for Social and Economic change, Bangalore, ISBN 978-81-7791-132-9

Khalique FB, Touhiduzzaman S, Islam S, Murmu H, RaselMd (2019) Economic analysis of rice production in Bangladesh; United International Journal for Research \& Technology, 1(2).

Leelavathi C, Naidu BV (2014) An econometric analysis of Agricultural Trade in rice crop of Andhra Pradesh, Journal of International Academic Research, ISSN: 2320 -5053, 2(5).

Maneesh P, Sankarnarayanan R (2016) A comparative study of trend in area, production and productivity of rice in Kerala and Tamil Nadu, Journal of Agricultural Economics, Extension and Rural Development 4(6): 468-475.

Rahman NF, Hossain I, Aziz A, Baten A, Kabir S (2013) Prospects of boro rice production in Bangladesh; advances in environmental biology, 7(14):4542-4549.

Web references:

https://www.india.gov.in/websitedirectorate-economics-and-statistics

\section{How to cite this article:}

Deepak Kumar Skand, Mukesh Kumar Wadhwani and Rahaman, M. 2020. Trend in Area, Production and Productivity of all Rice and boro Rice in Bihar State. Int.J.Curr.Microbiol.App.Sci. 9(09): 19671978. doi: https://doi.org/10.20546/ijcmas.2020.909.247 